\title{
Civil society and COVID-19 pandemic in Nagaland: Response in a Democratic Society
}

\author{
Moameren Pongen ${ }^{1}$, Dr. Chubakumzuk Jamir ${ }^{2}$
}

\author{
${ }^{1}$ Research scholar, Department of Political Science, Nagaland University, Nagaland, India \\ ${ }^{2}$ Assistant Professor, Department of Economic Yingli College, Longleng, Nagaland, India \\ Received: 02 Jul 2021; Received in revised form: 05 Aug 2021; Accepted: 11 Aug 2021 \\ (C)2021 The Author(s). Published by TheShillonga. This is an open access article under the CC BY license \\ (https://creativecommons.org/licenses/by/4.0/)
}

\begin{abstract}
Civil society plays a very constructive role in a society especially in times of a pandemic. The paper explores the role of civil societies in responding to COVID-19 pandemic in Nagaland. The whole state has been affected by the COVID-19 pandemic since early August-October 2020. Preliminary findings exhibits that civil societies played a vital role in providing emergency services, funding, volunteering, mutual aid, in-kind donations, and even policy advocacy. This article highlights that despite the state government with its limited resources was able to keep the pandemic crisis under control due to the active support and participation of civil societies. As respective civil societies within their own areas came forward in providing essential food and services to the most vulnerable sections of society which got affected the most by the imposition of total and partial lockdowns. This article suggests that the role of civil societies should not be overlooked in the context of pandemic management.
\end{abstract}

Keywords-Civil society, COVID-19, Nagaland, Neutral, vulnerable section.

\section{INTRODUCTION}

Development is one of the most important pillars of country's economic progress (Jamir 2021c; Ezung \& Jamir 2018). It is important that development helps in bringing changes on social, economic, political, cultural and comprehensive development needs comprehensive planning (Jamir 2019; Jamir 2020). In inclusive development, based on observed experience countries with the largest organization to the community bodies, civil societies have been successful. Because civil society is, direct supervisory power of the people on the rulers and authority's performance and gain their power by people's integration and movement. That is why the civil societies move towards organizing and distribution. Guilds, parties, media, trade unions and any group of people who are engaged in giving service, turned in to intervening group in government's performance and decisions. So that if decision is harmful, they do something like: demonstration, strike and which are civil activities and express their demands avoid conflict and remain on their positions as far as being convinced. This process is more powerful than controlling the different wings such as: parliamentary oversight, inspection organizations and involve society to the participation in political and social affairs. In countries were the position of people and civil society have been respected in the constitution in the framework of maintaining the legal freedoms and people's fundamental rights, the rate of development and reducing corruption is more obvious than the countries were constitution has not been respected. This guarantees one of the most basic foundations of development. Ankita Singh (2020) in one of her article Civil Society: The third pillar of strength in fight against coronavirus discusses about the crucial role the civil society has to play in minimising the impact of pandemic.

\section{RESEARCH METHODS}

The study primarily uses documentary information, including national and local government documents, news coverage, telephonic interviews, weblogs, citizen activists, and research reports. One of the authors also undertook participant observation between April and July 2020 in two NGO networks that focused their responses on the COVID crisis in Nagaland. 


\section{RESEARCH RESULTS}

Review the civil society responses in six aspects: emergency service, fundraising, volunteering, in-kind donation and policy advocacy.

\section{Emergency service by NGOs and partnerships}

NGOs have provided extensive service and support to those involved at the frontlines of the anti-COVID responses. Specifically, foundations collected and donated funding to support state-approved implementing organizations, mostly emergency response authorities and their affiliated charities. Only a handful of foundations coordinated and funded NGOs' epidemic response. For NGOs, a few emergency management NGOs and public health NGOs worked with state agencies, medical institutions, and foundations by delivering materials and services and assisting in epidemic prevention and control. Communitybased NGOs assisted local governments in their responses. In addition, volunteer, mutual aid, and grassroots groups comprising active citizens acted to help their neighbors and other affected people by providing personal and community services and collecting individuals' money and in-kind donations. Finally, business associations and professional associations have participated in collecting financial and inkind donations, mostly to state-affiliated charities and medical institutions (Zhang, \& Guo, 2020; Hu, 2020; Associated Press, 2020). NGOs with expertise in emergency response, health care, and information technology have increased. And more NGO networks were established to facilitate collective response. The changes can mostly be attributed to the striking increase of the number of NGOs in the past decade. However, NGOs have generally become less active and less autonomous in their emergency response due to the state's increasingly restrictive policies (Dong and Lu, 2020). Admittedly, a large proportion of NGOs took no responsive action in the epidemic.

\section{Fundraising for the epidemic response}

Funding by individuals and business unit has been a key way for civil society and individual to provide assistance to affected persons and areas during the COVID crisis. The crisis has been most pronounced in Kohima, Dimapur, Mon, Tuensang and Mokokchung.

\section{DISCUSSIONS: ROLE OF CIVIL SOCIETY DURING PANDEMIC IN NAGALAND}

In the midst of rising cases of COVID-19 in India and the chaos that was followed due to the sudden announcement of nation-wide lockdown, Nagaland government with limited resources was able to handle the COVID-19 pandemic to some extent. One of the reasons for the proper management of lockdown in the context of balancing the dilemma of protecting lives and providing livelihood was due to the positive role played by the influential and powerful civil societies (Jamir, 2021 \& Jamir 2021). From spreading awareness, raising funds, distributing masks and ration, implementation of states directives, civil societies were actively involved. One can cite the report of Nagaland Express where a group of people left food packages at designated areas in Kohima for the needy. Similarly, citizens in one of the district, ward leaders collected names of their members who were daily wage earners and arrange food items and other commodities to help them cope with the loss of their earnings (Jamir \& Ezung 2017; Abi-Habib, \&Yasir, 2020). Christian Religious institutions, which have a great influence in the Naga society, also came to the fore in providing support to government in the form of cash and kind in tackling the COVID-19 crisis by donating cash towards the COVID-19 relief fund and also offered the church premises to be utilized as a quarantine centre for civilian. Apart from the religious institution various unions like Nagaland NGOs Forum Mon unit donated cash to Mon district Task force for COVID-19, Dimapur District Autorickshaw Drivers Union distributed essential commodities donated by well-wishers. The union also provided ambulance service to those in need.

One of the active civil societies in Mokokchung district is that of Mokokchung Lanur Telongjem, they in collaboration with the District administration and other organization carried out various initiative for proper management of COVID-19 crisis. One of the executive member of the organisation highlighted that since the day of imposition of COVID-19 lockdown from March $24^{\text {th }}$, 2020 they have initiated various activities relating to proper management of COVID-19 pandemic. From fundraising to distribution of essential food commodities and even to the extent of supplying medicine in the border belt areas where there is problem of transportation. They distributed food items and other essential goods each to 18 wards under Mokokchung town to the needy person. They also conducted sensitization campaign of wearing mask, maintaining social distancing and using sanitization for more than two (2) weeks in and around the Mokokchung district. They also made masks and distributed free of cost to those who cannot afford it. They also visited COVID hospitals and done freewill donation. Apart from that, they made 3 video phases on COVID awareness and uploaded in various social media platform. They also took preventive measures to check the issue of black-marketing taking place by regulating prices of essential commodities on regular intervals and taking actions against those involved in hoarding of essential commodities. Furthermore they also checked on illegal entrance to prevent community spread. 
These civil societies through social media were also quite active with contact tracing and were immensely helpful in the process. Thus, during the period of lockdown in Nagaland the positive role of the various civil societies in Nagaland has enabling proper adherence to the lockdown rules. They in collaboration with the state officials also ensured that minimum standard of food were provided especially to those who lost their daily livelihood due to the lockdown (Shieh, \& Deng, 2011; Kyodo, 2020).

The role of civil society became crucial in the second as compared to the $1^{\text {st }}$ wave there was high positive rate of COVID-19 cases and increase in death rate (Jamir 2021) which left the state government with no option but to impose lockdown. The lockdown did not affect the salaried class especially employees under government services as they were getting their regular salary and less likely of being laid off from their job. However the decision which were made at the "war room" (Nagaland Post 2021) affected the business community, taxi drivers and daily wage earners the most. The closer of schools due to lockdown also affected those families whose livelihood was based on providing transportation service to school children. Further due to the pandemic home tuition was discouraged which affected those private tutors whose income was based on private tuitions (Rick, 2020). The pandemic also hit young entrepreneur's start up business since it halted their regular business which put some of them in debt since some took loan from banks and private lenders to start their business and some lost their jobs. Like the most of the states of India, Nagaland government also did not have any proper policy in place to take care of the economically weaker section of the society which not only got affected by the pandemic but also by the subsequent policies adopted by the government to manage the crisis. However the situation of helplessness and chaos that was seen in some states was not seen in Nagaland despite state government limited resources mainly due to the active role of the civil societies. One positive aspects of these civil societies was that most of them were citizens funded and not affiliated to any political parties. Thus almost all the civil societies came forward to help the needy on humanitarian grounds. For instance Chumukedima Ao Union with the donation from its members distributed $50 \mathrm{~kg}$ bag of rice to 186 needy families. Similar initiated was done at other colonies in different parts of Nagaland. The influential and powerful church organisation also came forward and donated money to district task forces. Like Ao Baptist Church Association (ABAM) provided financial assistance to Mokokchung District Task Forces for COVID-19 relief fund. Similarly Dimapur Ao Baptist Church provided oxygen cylinders to two hospitals under Mokokchung district. Under the Phek District Chakhesang Baptist Church Council (CBCC) provided financial assistance to the District Task Force, Phek district. Phevima Baptist Church arrange quarantine facilities for frontline workers. Khuzama Baptist Church provided food package for the needy in town areas. The Rector and Parish Priest Catholic Church Sechu Zubza offered the Don Bosco School under Kohima to be utilized as COVID care center. Apart from that different civil organization came to the front to provide relief for the needy. For instance farmers from Pfutsero distribute their produce for free in state capital Kohima. Muslim communities came forward to bury the death body of Covid patients. One Women group provided financial assistance to district hospital Dimapur. Nagaland Bhojpuri Samaj (NBS) provided ration to needy family in and around Dimapur. Bengali Youth Generation, an NGO distributed food package to the homeless and poor people in the town area since $19^{\text {th }}$ May. The important role of the civil societies in containing the pandemic crisis in Nagaland can be seen by the fact that Nodal officer for Dimapur COVID-19 activities appealed to various churches, NGOs and various organization to help out the needy(Gogoi 2021) which the civil duly respondent. In fact the civil societies were already active even before those appeals were made. Thus citizens from all walks of life and religious group came forward and played their part during the second wave. The active participation of the citizens enable the state government to spent their resources and funds from the central government in improving the health infrastructure of the state (Khan, 2020; Singh, 2020). The important role of civil societies especially in times of tackling a pandemic like the COVID19 can be seen from the experience of Singapore where recent reports suggest that the country which had a relatively good record at containing the wildfire spread of the virus is starting to see its infection curve rise up again. The second wave of infections has been traced mainly in three clusters, two of which are residential dormitories while the third is construction site. Therefore as India moves out of its lockdown, certain sections of people-mostly workers in the industrial and farming sector-will return to their workplaces. It is imperative for them to understand that the world they will return to is significantly different and their regular day-to-day behaviours will have to changemaintaining social distancing, full time use of masks, regular sanitization and maintaining hygiene-if we are to avoid a second wave of infections. It is extremely difficult to achieve this degree of behavioural change, especially social distancing, in a country like India with its tight knit communities. Highly sophisticated, a multi-channel communications effort is required for a large scale public understanding of "best" behaviours in such a case. NGOs can play a significant role in ensuring that these behaviours, 
become a second nature, something people can do on their own without any coercion (Ankita, 2020).

\section{CONCLUSION}

The pandemic has greatly exposed the systemic flaws and brought in the surface the drastic inequality in our society. The study found that privileged minority were able to isolate themselves and work from home without worrying about their future income. However majority of the population had no choice but to risked their own health and the health of their families to keep food on the table as it was the marginalized and poorest populations who were hit hardest not only by the virus but also by the global economic crisis (Rick, 2020; Spires, 2020). It was in such scenario that civil societies came to prominence and provided relief to this marginalized population especially in countries where the government distribution system is weak. Similarly the role of civil societies of Nagaland was imperative in the proper handling of COVID-19 crisis by the state government. In fact more than the state government agencies, the civil societies came to the front in providing relief to vulnerable section of the society. Thus civil societies has an important role to play in the proper implementation of government policies for the benefit of the citizens especially for the vulnerable section of the society which becomes even more crucial in times of crisis like that of Covid-19 pandemic. It is also essential for civil societies not to get embroiled in the party politics and keep themselves neutral to maintain it credibility and trust among the public, as their success and effectiveness mostly depends on the public support. Which can be seen by the fact that some celebrities along with well-wishers were able to arrange transportation to thousands of migrant labourers and students stuck in various states to reach their homes on regular bases (Dixit 2020) whereas on the other hand state government and opposition party were playing politicsoverthe issue at the expense of the poor helpless citizens (Rashid 2020). Therefore it is essential that civil society keep itself aloof from party politics and provide representation to the marginalize sections of the society, act as a watchdog over the government abuse of powers and act as a channel of communication and trust between the government and the people which will be crucial when recovering from the pandemic and resetting the economy.

\section{Photo:}

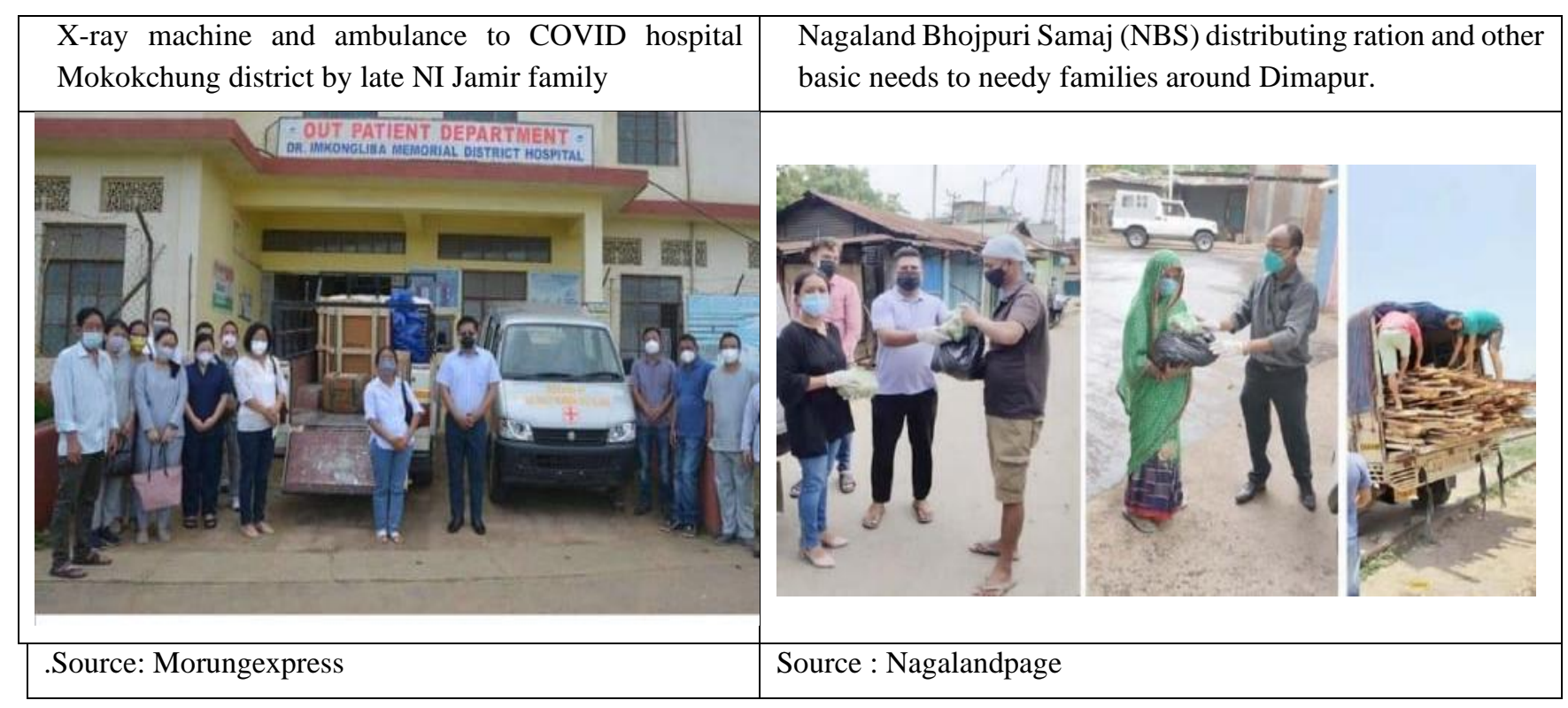

ANMA integrated Development Association (AIDA), the planning and development office of Salesians of Don Bosco ,Dimapur province providing dry ration to the needy families 


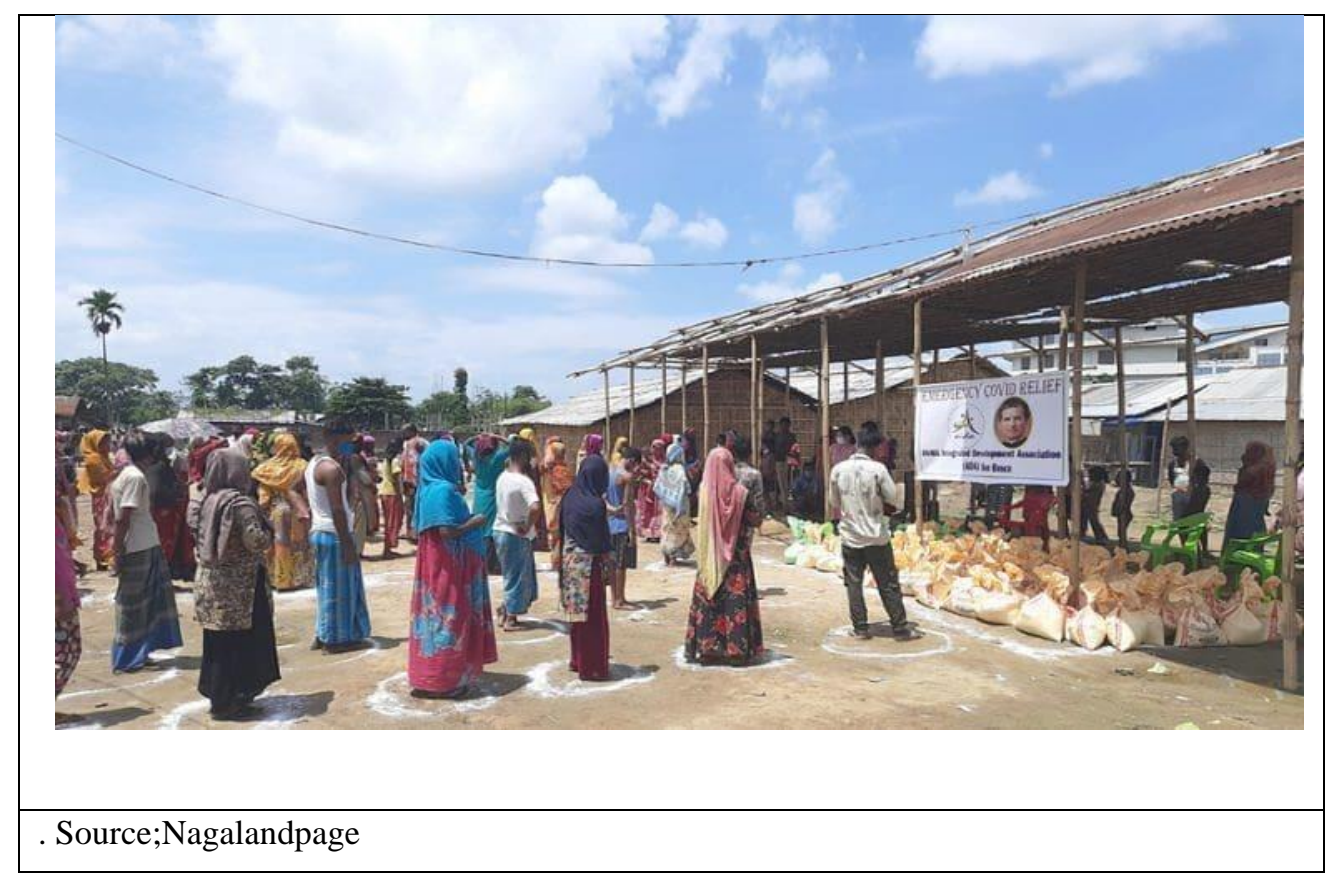

\section{REFERENCES}

[1] Abi-Habib, M., \& Yasir, S. (2020). India's coronavirus lockdown leaves vast numbers stranded and hungry. New York Times.

[2] Associated Press. (2020). Virus outbreak poses massive challenges for US charities. The New York Times.

[3] Dixit,P.(2020). Sonu Sood is the new Sushma Swaraj, helping stranded Indians one Twitter request at a time. The Print. https://theprint.in/opinion/pov/sonu-sood-is-the-newsushma-swaraj-helping-stranded-indians-one-twitterrequest-at-a-time/428589/

[4] Ezung, T. Z., \& Jamir C., (2018). Disparities in infrastructural development of Nagaland: A case study of Kohima and Longleng district, Economic Affairs, 63(2), 375-379

[5] Gogoi. B. (2021). Nagaland: Plea to help poor Covid-19 patients in Dimapur. Northeast Now. https://nenow.in/northeast-news/nagaland/nagaland-plea-to-help-poor-covid-19patients-in-dimapur.html

[6] Hu, M. (2020). Making the state's volunteers in contemporary China. Voluntas: International Journal of Voluntary and Nonprofit Organizations. Advance online publication.

[7] Jamir, C. (2021b). The first and second waves of the coronavirus (COVID-19) pandemic in Nagaland: across sectional analysis, RESEARCH REVIEW International Journal of Multidisciplinary, 2021; 6(6):95

[8] Jamir, C. (2021a). Impacts of social and economic determinants of coronavirus disease (COVID-19) in Nagaland: An empirical analysis. International Journal of Advanced Scientific, 6(2), 36-46

[9] Jamir, C. (2021c). Economic Inequality and Development of Nagaland. Mittal Publication House, New Delhi

[10] Jamir, C., \& Ezung T.Z. (2017). Poverty and Inequality in Nagaland, International Journal of Arts Humanities and Management Studies, 3(6), 64-72.
[11] Jamir, C. (2020). Infrastructure Development in Rural Nagaland in B. Kilangla Jamir and Giribabu M. (Eds.) Agriculture and Rural Transformation: Issues and Challenges (with Special Reference to North East India), Rawat Publications, 305-314

[12] Khan, M. (2020). The EU fights the coronavirus on all fronts. Financial

Times. https://www.ft.com/content/2e49bbc4-67dc-11eaa3c9-1fe6fedcca75.

[13] Kyodo, J. (2020). Japan may dish out cash to households impacted by coronavirus. The Japan Times

[14] Rashid,O.(2020).Coronavirus lockdown/U.P. government locks horns with Congress over buses for migrant workers. The Hindu. https://www.thehindu.com/news/national/otherstates/coronavirus-lockdown-up-government-locks-hornswith-congress-over-buses-for-migrantworkers/article31622653.ece

[15] Rick, J. (2020). Reasons why civil society is essential to COVID-19 recovery. https://www.weforum.org/agenda/2020/05/why-civil-society-isessential-to-covid-19-pandemic-recovery/.

[16] Schwartz, J., \& Evans, R. G. (2007). Causes of effective policy implementation: China's public health response to SARS. Journal of Contemporary China, 16(51), 195-213.

[17] Shieh, S., \& Deng, G. (2011). An emerging civil society: The impact of the 2008 Sichuan earthquake on grass-roots associations in China. The China Journal, 65, 181-194.

[18] Singh, A. (2020). Civil Society: The third pillar of strength in fight against coronavirus. https://government.economictimes.indiatimes.com/news/go vernance/civilsociety-the-third-pillar-of-strength-in-fightagainst-coronavirus/75642349

[19] Spires, A. J. (2020). Regulation as political control: China's first charity law and its implications for civil society. Nonprofit and Voluntary Sector Quarterly, 49(3), 571-588. 
[20] State level war room on COVID-19 (2021). Nagaland Post.https://www.nagalandpost.com/state-level-war-roomon-covid-19/232743.html

[21] World Health Organization (2018). Risk Communication and Community Engagement (RCCE) Considerations: Ebola Response in the Democratic Republic of the Congo. Geneva: World Health Organization; 2018

[22] Zhang, Z., \& Guo, C. (2020). Nonprofit-government relations in authoritarian China: A review and synthesis of the Chinese literature. Administration \& Society. Advance online publication.

[23] Zhang, Z., Shen, Y., \& Yu, J. (2021). Combating COVID19 together: China's collaborative response and the role of business associations. Nonprofit and Voluntary Sector Quarterly. 